\title{
Challenges in Administering Property Value Capture in Tanzanian Cities
}

\author{
Ally H. Namangaya \\ School of Spatial Planning and Social Sciences, Ardhi University, Dar es Salaam, Tanzania \\ Email: namangaya@yahoo.com
}

How to cite this paper: Namangaya, A.H. (2019) Challenges in Administering Property Value Capture in Tanzanian Cities. Open Journal of Business and Management, 7, 1412-1428.

https://doi.org/10.4236/ojbm.2019.73097

Received: June 10, 2019

Accepted: July 23, 2019

Published: July 26, 2019

Copyright $\odot 2019$ by author(s) and Scientific Research Publishing Inc. This work is licensed under the Creative Commons Attribution International License (CC BY 4.0).

http://creativecommons.org/licenses/by/4.0/ (c) (i) Open Access

\begin{abstract}
Most of urban areas in Africa, including in Tanzania, are facing huge infrastructure gaps that require innovative financing mechanisms. Due to the rapid pace of urban development in Africa, land or property value capture could be one of the effective strategies for raising much-needed resources. The paper, using cases of two projects in the Dar es Salaam metropolitan area, examines how the preconditions of implementing land value capture instruments prevail in Tanzania. It evident from the analysis of the legal context and the projects, concerning the prevalence of supportive preconditions for applying value capture instruments, the laws and urban management practices are quite superfluous in their provisions and proposals such that they do not give the required force, although general mandates are there. Impliedly, the laws and practices were designed without a specific focus or outlook towards making applications of property value capture instruments possible. This is a critical area that requires intervention to improve the financing of urban development needs in Africa.
\end{abstract}

\section{Keywords}

Land Value Capture, Property Value Capture, Urban Financing,

Dar es Salaam

\section{Introduction}

Africa urban population is said to have increased 14 folds in the last 60 years from 32 million to 450 million in the mid-2010s and is expected to triple to 1.3 million in 2050 [1]. This ever-increasing population is coupled with increased demand for land and real estate development which tries to emulate property market development in middle and far eastern counties [1] [2] [3]. On the other hand, the increased populations create increased demand for infrastructure fa- 
cilities in the context in which there is already an enormous gap. To give specific examples in Tanzania, the urban population in Tanzania is doubling every 14 years from its growth rate of 5.2 percent per annum [4]. At the same time the percentages of urban residents getting electricity, piped water, solid waste collection services and use sewers or septic tank for sanitation are 46, 25.6, 24 and 9.1 respectively [5]. Similar statistics of servicing deficits are discussed in Nigeria, Kenya, Ethiopia and Rwanda [2] [6] [7].

The servicing deficit is a result of the inability of local and central governments to raise resources to finance planning and infrastructure provisions [8]. It is argued that Africa needs to spend US $\$ 93$ billion annually or 15 percent of its GDP, which is in average a double of African countries spend now [1] [6] [9]. For instance, in Tanzania for the year 2011/2012, the development budget per capita ranged from about US $\$ 0.06$ in Dar es Salaam to an average of about US $\$ 0.18$ in smaller cities [8]. In contrast, the estimated per capita requirement (even without accounting for the backlog) was US\$120 [10]. Dependence by city authorities in Africa on traditional sources of financing through budgetary subsidies to a tune of 70 percent has been blamed for many cities' inability to finance infrastructure [2] [6] [11] [12]. This trend has resulted into a call for African context-specific researches into the potentiality of use of land-based financing tools like property value capture to mobilise resources for funding infrastructure development in Africa [1] [6] [12]. This paper embarks on empirical researching gaining at sharing Tanzanian experiences on legal and operative conditions in the country militating against the applications of property or land value capture instruments.

The paper has six sections. The first Section looks into the meaning of property value capture. It also expands to the second section where the theoretical base of the paper is discussed by examining different instruments in use worldwide for property value capture and the factors for their successful applications. The discussions on the data sources and limitations of the paper follow. The empirical part starts with examining legal regimes in the country and how they provided a sufficient basis for applications of PVC instruments discussed previously. The fifth Section is where the detailed account of the cases used for the study is presented. The sixth Section is a discussion of the results, which concludes this work.

\subsection{Meaning and Importance of Property Value Capture}

Property Value Capture (PVC) entails accrual of financial dividends by the government as a result of increased property/land values or demand for land from interventions by municipalities [13] [14]. The increases in land values created by changes in quality, zoning, limitations or caveats, densities, or other physical or policy improvements in the land may cause alterations in the supply to demand ratios, thereby increasing its desirability. These increases in supply to demand ratios can be monetised, and the returns of that monetisation can then be used 
by the municipalities as a source of revenue. Therefore, the basis for value capture is "those who benefit from a particular infrastructure, service or a windfall should also pay for it" [15].

While the costs of utilities, which these urban councils fail to meet have the potential of being recovered through user fee, the costs of transport infrastructure projects like rapid bus systems and city rails, which are critically missing in the many African cities, are said to be very expensive such that fare boxes can only meet at a maximum 60 percent of operational costs [16].

The quality of the land may be influenced by multiple factors which are called sources of increment in value. The typical sources of increment value include:

- the increase in the need of the particular use of the land due to the increase in the number or value of users;

- land use regulations that increase the usability of the site;

- infrastructure supply that increases in the number and quality of users;

- reduction in the cost of doing business or consumption in that particular site.

There is still scholarly debate as to whether land value capture should include normal taxes and charges e.g. property taxes charged by the government city wide or should be separated to include only deliberate location-specific interventions that concentrate on increments in the value of land [14] [17] [18]. The position of this paper is to focus on the latter category which helps in devising best practices for city managers.

\subsection{Deducing Preconditions for Successful Applications of Property Value Capture Instruments from Various Experiences}

There are several sources of PVC and appropriate instruments that governments can use to capture the value increments. This section emanates from the review of various experiences of practicing value capture instruments in different countries, from which the preconditions are deduced. The reviewed cases include uses market compensations and public housing in the Netherlands [19] [20], PVC in partnerships projects along transport corridors in USA and Colombia [16] [21] [22], PVC in land redevelopment projects in USA and Italy [23] [24] [25] [26], land readjustments in China and India [27] [28] [29] and various cross country examples [18] [27].

In these studies visited, first type of sources of value increment discussed is unrealised or under-appreciated increments in the value of land that occurs as a result of changes in land use over time, even without government interventions, but merely increase in population and consumers causing rising land values and development pressure [19] [21]. The development pressure leads to the attraction of higher value uses, and more intensive uses including higher building densities [20]. In such a context, governments can use instruments such as special tax assessment districts, re-development plans and issuance of development rights and bonus densities. These measures generally imply zoning of areas (with vertical development guidelines) such that these measures can be adopted. Major 
preconditions for successful use of zonal-based measures include having reliable baseline information on base values, value increments and property transaction information [22] [23] [24] [25] [26]. To be able to get useful base values and therefore derive value increments as well as to be able to monitor collections, one needs efficient database and systems of revenue collection [27] and development control, including enforcement of building codes such that the development pressure is enclosed in specific zones [18].

Another source of increments from the increase in property value is when government interventions to make land more available for investment from its own initiatives or from the initiatives of landowners. These measures ought to result in more space being available for use, horizontally or vertically [20] [28]. Direct investments in real estate, planning for new uses of land and buildings as well as site branding and marketing of areas as redevelopment zones by government or private landowners can facilitate the realisation of potential values of property [23]. Typical measures that make more land available in a city for investments include land pooling and readjustment, gentrification and transit-oriented redevelopment plans, sale of greenfield plots and sale of under-utilised brownfield properties. The value capture instruments focus on inner cities because they have development pressure [21]. Availing land in the developed part of the cities is usually a politically sensitive exercise because exiting developers or occupiers may feel threatened by the upcoming changes. Therefore local champions and political support of brownfield agenda must be ensured [20] [28]. Laws should also support bottom-up planning and market-oriented planning with planning authorities playing a facilitating role [21] [30]. In countries like the Netherlands where the measures are being applied regularly, the experiences show that there must be policies to protect low-income households in the areas that are being upgraded and very transparent system of assessing the impacts of the upgrading spatially and socioeconomically [23]. Therefore, it is imperative to have a long-term city redevelopment strategy where such redevelopment projects fit in [20] [21].

As hinted earlier, sufficient funding for infrastructure development has to rely generally on the use of property/land value capture tools, as fare boxes have very limited ability to pay the cost while meeting inclusivity objectives. The studies have established a very strong correlation between accessibility to transport infrastructure and raise property values. A study by Mathur [30] in the USA has established that a one percent decrease in travel time to the central business district increased the price of housing by between 0.072 and 0.254 percent depending on the age of the building. Vadali [31] discussing the case of Dallas, in the USA, found that houses situated between the distances of $400 \mathrm{~m}$ to $1.5 \mathrm{~km}$ from a new toll road or bridge, record an increase of the value of as much as 19 percent. The increase in value start being experienced even before the infrastructure has been built. For instance, it was found in Santiago, soon after the announcement of the plan to have metro constructed housing prices increased between 4.2 and 7.9 percent and after actual construction, the further rise of between 3.1 and 
5.5 percent was recorded [32]. As to the scale of immediate impact areas, studies indicate the distance of 800 meters for train station [33], 100 meters of rapid bus corridors [34], and generally for a percentage decrease in travel time to the CBD, by automobile increases property price by 0.07 to 0.7 per cent [16].

Investment in infrastructure services to generate increments in properties value may be done by government alone or in partnership with the private sector or by government facilitating the private sector to develop the infrastructure [21] [26]. Partnerships are preferred because they allow the private and public sectors to share not only the costs and risks of the public investments but also the associated benefits [22] [25] [34] [35] [36] [37] [38]. Also, the involvement of the private sector has possibilities of reducing market distortions in the property market since government valuations of land tend to be less reflective of market rates [20]. Value increments are also a mechanism which could reduce the uncertainty around the timing and approval process, thereby lowering risks to private investors. This type of mutually beneficial arrangement could be a joint venture funding and pre-agreements on conditions that are less susceptible to policy shifts [20].

Measures for value increment capture on and around infrastructure investments projects include instituting betterment charges for properties whose values rose due to the enactment of the infrastructure. Also, government acquisition of land around developed infrastructure to resale it at a premium price or attract special uses with higher rent paying capacities. The government, in additions to getting a share of profit from the joint infrastructure projects, may also give developers conditions to develop pubic amenity projects such as gardens, social housing or access roads. Preconditions for successful infrastructure projects with government support include the presence of institutional structure for fostering binding agreements and implementation procedures between parties [17] [21], and local governments having the power to borrow or enter into negotiations with the private sector [18]. If there are special laws that allow subsidisation for publicly beneficial projects, then local governments may have a room for issuing development rights or requiring investors to undertake special subsidised social projects [19].

\section{Data Sources}

This research originated from an attempt to establish the best practices of property value capture in Tanzanian cities for disseminations of best practices among urban managers. Interviews and documents review was undertaken in the five municipal councils in Dar es Salaam City, Kibaha town council and in the ministries responsible for lands, local government and infrastructure development, as well as with parastatals involved in infrastructure financing and provisions. Twenty-two cases of land and infrastructure projects have been undertaken by the municipalities and government entities either alone or in cooperation with the private sector. These projects were seen to have the potential of generating sustainable revenue for the government, but it was observed that in reality, the 
government had gained very little in a way of property value capture in all projects. Therefore it was imperative to explore in depth the reasons for the government failure to gain from the use of PVC instruments. The two cases among 22 were selected for the in-depth analysis.

The study analyses the context conditions through evaluating the two cases, one of availing land by landowners through the local government, which is a recent common practice in Tanzanian cities [39] and the other a unique infrastructure development under a public-private partnership arrangement (Figure 1). The two cases where chosen because they represent different types of projects and their commonality in international experiences in the use of property value capture.

The study uses projects data and official records from developers and government entities obtained through interviews with officials in the Ministry of Lands, Housing and Human Settlements Development (MLHHSD), urban council officials in Kibaha, Temeke and Kigamboni, and those from developers companies including Space \& Development Company Limited and the National Social Security Fund (NSSF). Legal instruments are studied initially to give a context in the discussion of the cases. The tendency of property value capture studies to rely on the recorded secondary data is one of their major limitations, including for this study. This is because the changes in value appear across a relatively long span of time, where human memory is less reliable. Therefore official records become the major data assembly method coupled with observations.

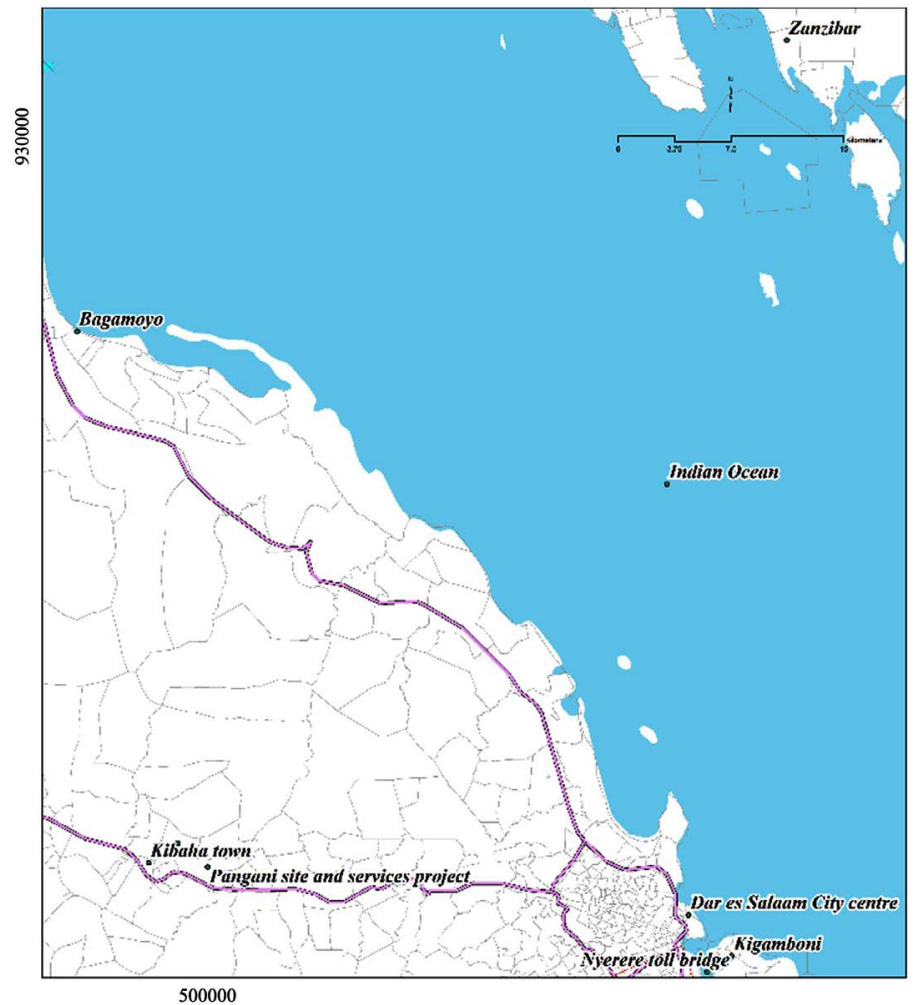

Figure 1. Location of projects. 


\subsection{Supportiveness of the Legal Set up in Tanzania to the Applications of Land Value Capture Instruments}

Main laws that seems to facilitate the prevalence of reconditioned for successful applications of value capture include the Land Act of 1999, Urban Planning Act of 2007 and the Guidelines for Preparations of Planning Schemes of 2007; Mortgage Financing Act of 2008 and Unit Titles Act of 2008, Public-Private Partnership Act of 2014, Local Government Authorities Act of 1982, and Local Government Finances Act of 1982.

Urban Planning Act of 2007 and the Guidelines for Preparations of Planning Schemes of 2007 provide for the preparations of urban redevelopment and urban renewal plans. Planning Regulations of 2018 have added requirements for density specifications, through zoning of areas by floor-area-ratio as indicators of densities. However, most of the plans have focused on horizontal zoning but do not reflect on vertical and time zoning, to allow effective use of spaces between different times [40]. Also, the Land Act of 1999, urban planning directives of 2019 and the earlier planning directives provide for land regularisation and residential licenses, and the recommended density for the regularisations plan to take place. However, they do not state the target density for regularised areas which means any density could be designated regardless of the prime nature of the regularised areas. The Land Act of 1999 includes land pooling and regularisation as part of interventions in urban areas, but this is not mainstreamed in the legal instruments for planning, as a result, most of the planning is done without the respect of boundaries of ownership [41]. Landowners are empowered to initiate and prepare their own plans by the legal instruments for planning. However, this availing of land is often done in peri-urban areas and without the necessary infrastructure [42].

The Mortgage Financing Act of 2008 and the Unit Titles Act of 2008 provide for high-rise development, condominiums, and gentrification without specifying value capture issues. The local government financing provides for databases for taxes which depend on valuations of properties in urban areas. This could form a basis for baseline data for value increment establishment. However, most of these valued properties do not have accompanied spatial data to facilitate the designations of tax districts [43]. The laws are silent on the use of the terms special tax districts and bonus densities. Equally data on land transactions and rent contracts between property owners are rarely legally recorded and even whey are do they do that with central government taxing authority (Tanzania Revenue Authority) whose databases are not synchronised with local governments land value databases [44].

As per the Land Act of 1999 and Urban Planning Act of 2007, the Commission of Lands was supposed to establish the rate and applicability (guidelines) for betterment charges which has not (yet) taken place. Therefore even when there is obvious evidence of gains by property owners from an infrastructure project, there is no legal basis for betterment fees. However, as per the Local 
Government Finances Act of 1982, a local authority in consultation with the minister responsible for local government may establish a specific tax or rate applied to a particular location. This opens a room for the establishment of special assessment tax districts.

On the point of joint development of infrastructure projects, local government are legally allowed to borrow from banks, but they need a not-easy-to-obtain permit from the Treasury Registrar who is in the central government. As per the Public-Private Partnership Act of 2014, local government are supposed to engage in PPP, but the central government are yet to formulate regulations on procedures and ceilings to govern the partnership arrangements. Moreover, local government cannot form an agency hence there are legal limitations to have separate institutions to manage projects as per Local Government Authorities Act of 1982.

\section{Case 1: Availing land for new developers through landowners}

The case presented is that of Kibaha Town Council which is situated around $35 \mathrm{~km}$ from the CBD of the Dar es Salaam City, where there was a project to avail land for development on a site which was $4.5 \mathrm{~km}$ from Kibaha town centre (MailiMoja). In terms of development, the site is generally in the same state as many peri-urban parts of Dar es Salaam, which is the commercial hub of Tanzania and among the three biggest cities in eastern Africa. The landowners of the 68 acres of tilted farmland had decided to avail their land for property ownership. They contacted a private company to prepare the land and sell as surveyed plots. In 2014 when this decision was being undertaken the owners of the land had valued it at T.Shs. 15,000,000 (about US\$9033) per acre ${ }^{1}$. The developer agreed to prepare a detailed plan and survey plan (plots subdivision through cadastre surveying). The site preparation also included the provisions of site access and intrasite major roads with pressed stony-earth surface and culverts, electricity service line as well as piped water network. All these services were extended beyond the site to where major roads and service lines would pass, as the trunk lines were three kilometres away. The Kibaha Town Council and utility agents had promised these trunk service lines for water and electric would be extended to the entry point of the site within one year (by 2015). Tanzania electric company (TANESCO) and Dar es Salaam Water Supply Authority are national utility agencies accountable to the Ministry of water through Regional Administrative Secretary. They are not responsible to the town authority and are not required to share their plans with the authorities, although city major (town council's chairperson of elected ward councillors representatives) and Town Council Executive Director, who is an appointee of the president, are members of the DAWASCO boards. The town master plan also indicated that the site location was a part of the town where the town central business district would be located. The plots are supposed to be sold through the council as the laws in Tanzania allows only the government to sell or allocate plots. The agreement was also that ${ }^{1}$ June 2014 a US\$ was equivalent to T.Shs. 1660.5. 
as a part of land value capture, the council would get 10 percent of gross sales, in additions to premiums and land rents. All costs of ruining the project including advertisement would have to be paid by the company, who got loan financing from the TIB Development Bank.

The costs of the whole project as obtained from the developer (Table 1) was T.Shs. $2,432,708,920$ and the total area obtained was $333,049 \mathrm{~m}^{2}$, which means the cost per sellable areas of plots was T.Shs. 7304.4 per $\mathrm{m}^{2}$, which is about US $\$ 3.3$ per $\mathrm{m}^{22}$. On the other hand, the ministry responsible for lands in 2016, had designated the price of a square meter of land with minimum services in the site and areas around it to be T.Shs. 15,000 or US\$6.6. The difference between the actual investment costs and designated sell price of land has motivated many local governments to embark on availing land in new area plots projects, mostly without investments in utilities, as a source of income [39].

Since 2015 to date, the major hurdle to the development of the site was provisions of the water and electricity trunk lines close to the site. Despite the fact that the utility companies promised to provide trunk service lines close to the site, and were paid for the infrastructure development costs within the site, they have not been able to fulfil this obligation. When interviewed their response was they have a backlog of demands of servicing and therefore the plans from the headquarters are to serve developed areas of the town first. The same observations are made by Kironde [42] when discussing the case of " 20,000 " plots project in Dar es Salaam where the government planned plots are deprived of infrastructure while utility agents are servicing unplanned areas.

With no services, plots in unplanned areas are cheaper than those in planned areas. For instance, Alananga [45], using data from 2010, established a price of $400 \mathrm{~m}^{2}$ peri-urban plots to be T.Shs. $1,000,000$ which is equivalent of US $\$ 1.85$ per $\mathrm{m}^{23}$. A similar range of between US $\$ 0.6$ per $\mathrm{m}^{2}$ and US $\$ 2.5$ per $\mathrm{m}^{2}$ was previously established by Kombe [45] in an empirical study of peri-urban areas of the same city. The relative cheapness in unplanned areas is because many costs involved in titled areas such as for planning, cadastre surveys, premiums and land rents are not imposed in unplanned areas. These areas also are not exposed to development conditions like conforming to building codes or requiring to develop the site within three years since being allocated the plot. The government also has no policy on restricting land sales or development in informal areas. An additional reason given in the literature is the plots in informal areas are rather small and therefore affordable, where the majority have less than 300 $\mathrm{m}^{2}$ [46]. This is in contradictions to the standards in planned areas where the minimum plots sizes have been $400 \mathrm{~m}^{2}$.

According to project developers, the site fails to develop because prospective plot owners would like to see water and electricity provided in proximity to plots. This is also in conformity to the other studies that have established that housing development in Tanzania is not shaped by plots availability and plans ${ }^{2}$ In June 2016 exchange rate was T.Shs. 2190 per US\$.

${ }^{3}$ In June 2010 the exchange rate was T.Shs. 1350 per 1 US\$. 
Table 1. The costs of availing land in peri-urban areas (Kibaha) town project.

\begin{tabular}{ll}
\hline Cost item & $\begin{array}{l}\text { Tanzanian } \\
\text { Shillings }\end{array}$ \\
\hline Site Area (68 Acres) at the price of T.Shs. 15 million per acre & $1,020,000,000$ \\
Change of use, and planning costs & $30,000,000$ \\
Cadastre survey costs & $30,000,000$ \\
Promotions and marketing costs & $28,000,000$ \\
Road walks, across the kite with culverts & $228,240,000$ \\
Electricity, access within 50 m of each plot, to be curved by connection costs & $150,000,000$ \\
DAWASCO pipe water lines, access within 50 m of each plot, to be curved by & $234,830,000$ \\
connection costs & $24,839,000$ \\
Deep Bore-hall to complement piped water (T.Shs. 725,909,000) & $319,399,960$ \\
20\% interest on capital in the first two years & $48,000,000$ \\
Sales costs (two sales personnel and infrastructure guards) in the first two years & $2,432,708,920$ \\
Total development costs & 333,049 \\
Area of plots (saleable land) & 7304.4 \\
\hline Cost per m ${ }^{2}$ & \\
\hline
\end{tabular}

Source: Space \& Development Co. Limited, the project's developer.

guidance but access to infrastructure services, particularly water and electricity [47]. Consequently, the site and many other sites in the city fail to develop, and the expected income in terms of land value capture by the councils is not realised.

\section{Case 2: Private funded toll bridge project in Kigamboni}

Prior to 2016 the Kigamboni settlement, which is just about one kilometre away across the creek to the central business district of Dar es Salaam city, was difficult to access except by a ferry or by travelling for over $50 \mathrm{~km}$ through the southern side of the city. It was decided to construct a bridge in a part of a bay that holds the Dar es Salaam Port and sea marshland. The feasibility study carried out before the execution of the project highlighted that the project required USD 136 million whereby the capacity of the government immediate budget alone was not sufficient to finance the project. Therefore, the government sought to realise the project through a partnership between the central government and NSSF which is a pension fund. The original agreement was NSSF to contribute $60 \%$ of the estimated construction costs while $40 \%$ was to be paid by the central government. In other words, the bridge was constructed in a public-private partnership approach between the ministry of transport and NSSF. However, the central government did not honour its obligations and therefore the pension fund alone financed the project.

The projected income indicated was only bridge tolls on users' vehicles. The terms and conditions on the project were for NSSF to construct and operate for 30 years (to be reviewed after every ten years) to recoup the costs and transfer 
the said asset back to the government. The bridge started operating in April 2016. The average annual collections were US $\$ 7$ million. All the revenue collected from the project is from drivers who use the bridge and pay the bridge toll

Prior to the construction of a bridge Kigamboni as a whole, immediate area near the bridge was generally underdeveloped. However, since the operations, local land brokers (madalali) attest on increasing demand for buildings land and retail spaces. This can be confirmed by the data from MLHHSD that showed a jump in price per unit area of residential and commercial property after 2016 (Table 2). The project data using a scenario of no bridge vis a vis those of observed data shows that in two years after the start of bridge operations, there is over 100 percent jump in value. When council experts in Temeke and Kigamboni were asked of the benefits that they obtained from the bridge, they responded that they did not have direct income from the bridge or areas between but as the part of town development they were likely to get benefits from property taxes, business licenses and other indirect income from the development of the area. In a nutshell, the local authorities have no mechanism to capture the observed increments in value. Even data on increase in property prices are not available in the councils, and the same data have not been used by the MLHHSD to set some strategy to capture the increment in value.

\subsection{Summary of Limitations to Applications of Land Value Capture Instruments}

After analysing the preconditions for successful implementation of land/property value capture instruments as principal tools for financing urban infrastructures, and the Tanzanian legal context, it is apparent that Tanzania laws neither prohibiting the use of the instruments nor do they specifically foster their applicability by creating an enabling and environment for their applications. This indicates a systemic unawareness of the tools and their potentials for their use among urban financing professionals and policymakers. Moreover, planning practice in Tanzania is generally focusing on horizontal zoning of land uses, thus limiting the room for effective use of areas supplied with basic infrastructure facilities.

Table 2. Changes in per property prices in Kigamboni.

\begin{tabular}{ccccc}
\hline Year & $\begin{array}{c}\text { Residential plot price } \\
\text { in US } \$ \mathrm{~m}^{2} \text { projected } \\
\text { without the bridge }\end{array}$ & $\begin{array}{c}\text { Residential plot } \\
\text { price in US } \$ \mathrm{~m}^{2} \\
\text { with bridge }\end{array}$ & $\begin{array}{c}\text { Commercial plot price } \\
\text { in US } \$ \mathrm{~m}^{2} \text { projected } \\
\text { without the bridge }\end{array}$ & $\begin{array}{c}\text { Commercial plot } \\
\text { price in US } \$ \mathrm{~m}^{2} \\
\text { with the bridge }\end{array}$ \\
\hline 1996 & 0.5 & 0.5 & 0.7 & 0.7 \\
2006 & 0.8 & 0.8 & 0.9 & 0.9 \\
2010 & 3.4 & 3.4 & 5.5 & 5.5 \\
2013 & 5.5 & 5.5 & 8.2 & 8.2 \\
2016 & $7.5^{*}$ & 16.3 & $16.2^{*}$ & 21.3 \\
2018 & $12.5^{*}$ & 31.5 & $18^{*}$ & 38.7 \\
\hline
\end{tabular}

* indicates exponentially projected values. Source: Valuations sections of MLHHSD, 2019. 
As laws also allow detailed plans to be prepared in isolations, many of the plans are prepared in the absence of citywide redevelopment strategy which makes selective applications of value capture instruments politically unfair and incoherent. This has been the case in Kibaha town as the project site was isolated from other neighbourhoods under development.

The observable fact in the case of Kibaha project is lack of linkages between the initiatives to avail land by the landowners and local authorities and provisions of necessary infrastructure to make envisaged development realisable. As seen from the case of Kibaha, the consequence has been the development continuing to be informal and spread in areas that have infrastructure services (Figure 2), as stated earlier, it is infrastructure availability and not land that determine the pace of development [47]. The longer-term impact of this pattern has been that, although projects on availing land are numerous, the informal development along corridors with infrastructure facilities continues unabated. Worse still, the payment of 10 percent the local authorities obtain from sale of such underserviced land will have to be compensated rather expensively by the costs of retrofitting infrastructure services in the future.

The main contributing reason to the failure to match land use plans with infrastructure development in Tanzania is the absence of functional linkages between plans and budgets of utility agents and those of local authorities (planning authorities). Utility companies as line agencies of the central government are not accountable to local authorities, while on the other hand regulations patterning to land use planning make it optional for local authorities to engage and take up proposals of utility agents. With increasing trends of local authorities to engage in the sale of land as the way of generating own source revenue, the utility companies and urban local authorities operate in a contradictory logic. Utility companies maximize their profit by servicing inner-city areas, including informal areas where there is already development hence immediate customers and voters, while urban authorities focus on peri-urban areas where land is available and relatively cheap, and since they are not responsible for servicing, and their "profit" margin is higher. This is the dilemma in coordinating land use development in Tanzania.

The case of Kigamboni shows that there is generally lack of baseline data for applications of land value capture. Even when a new project is being developed as the case of Kigamboni toll bridge, initiatives are not taken up to develop the database or undertake a baseline study and plan for future delineations of the special tax assessment district. Data on land values and potential impact area of the bridge were not accumulated by the local authorities. As a result of this deficiency, the obvious knowledge available on the benefit obtained by the project cannot be quantified. Even when such quantities have been identified under a separate project, as in the case of Kigamboni general land prices, such data are not available to the councils. Figure 3 shows zones along the Kigamboni Bridge that warrant planning interventions that would facilitate capturing the value generated by the toll bridge, but such plans and development guidance have not 
been provided. Hence there is along the bridge many vacant plots, unplanned low-density development and underutilised industrial areas.

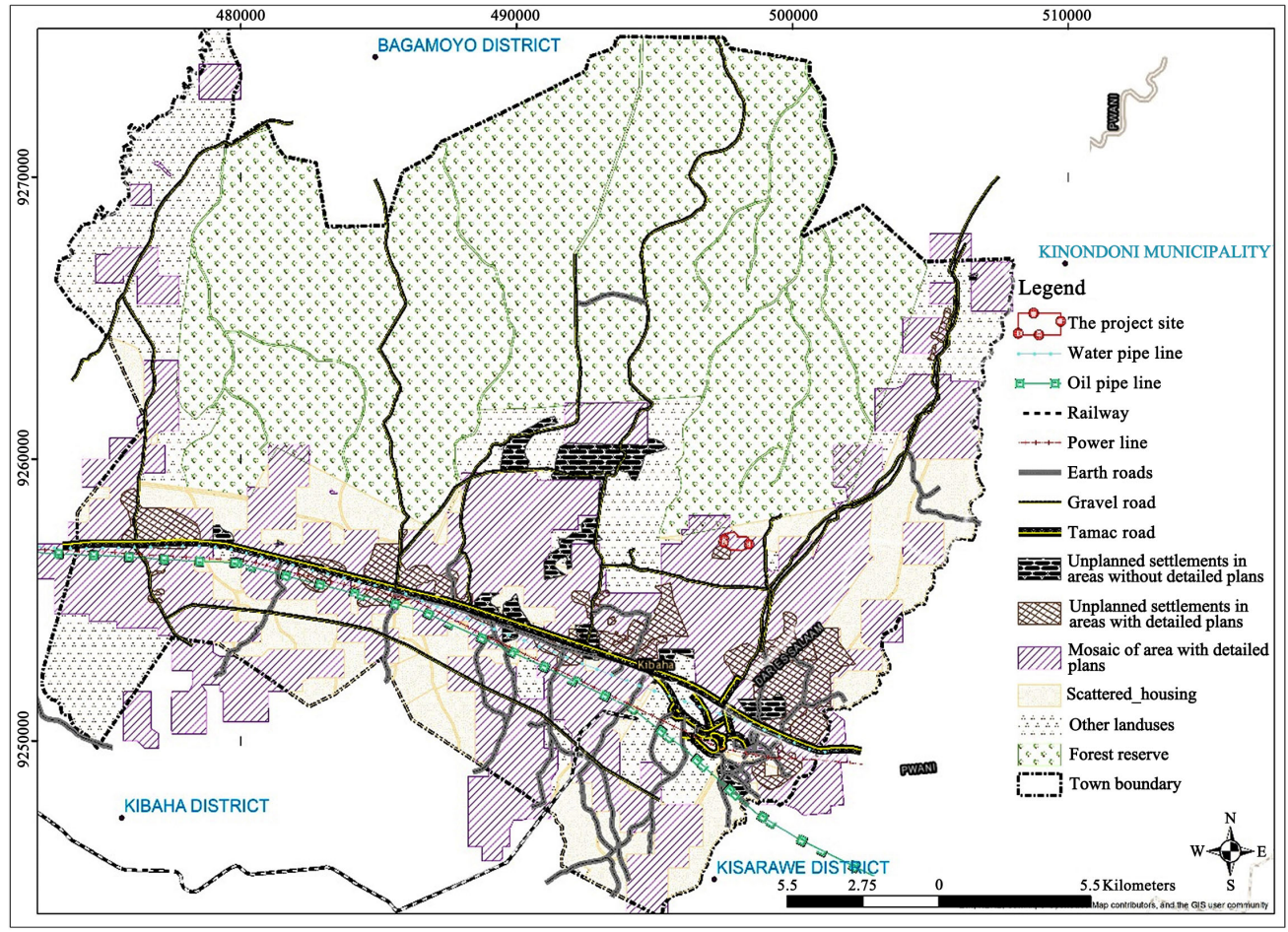

Figure 2. Patterns of informality in planned areas Kibaha town due to inaccessibility to services. Source: Kibaha Town Master Plan 2017.

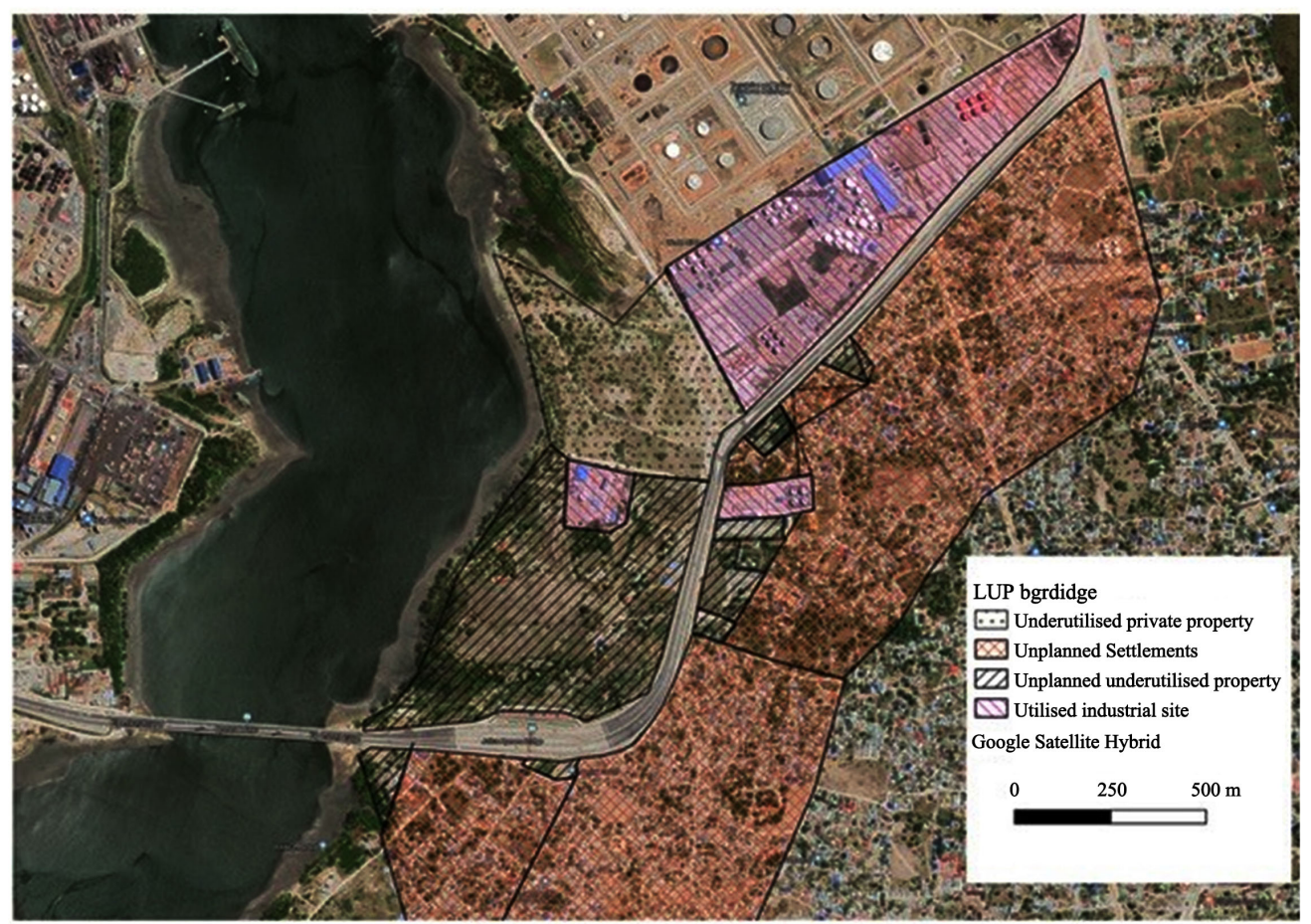

Figure 3. A potential tax assessment district in the area immediately affected by the Kigambonibridge. Source: Delineation on google image of 2019. 


\section{Conclusions}

Despite the dire need and enormous potentials for financing urban development in Tanzanian cities through land value capture, there is a systemic unawareness in the country among professionals and policymakers. Although fundamentals are there, laws and planning practices do not go to a specific level of requirements and proposals that would make the application of value capture instruments possible and enforceable. Due to this unawareness of the use of land/property value capture instruments in financing infrastructure, some approaches to raising resources through availing land are even detrimental to long term goals of developing serviced cities. One such area is the development which does not focus on creating a healthy relationship between proposed spatial density, infrastructure availability and database development for value capture [1] [2] [9] [25] [26]. Comprehensive value capture strategy is employed though city master plans and redevelopment plans should also be one strategic focus area as these planning and urban management instruments are already in practice and thus they require less policy reform to except them to the issues of facilitating value capture instruments [1] [20] [21].

In terms of policy implications, it is important therefore to have parallel initiatives of mainstreaming property value capture issues be undertaken. The first intakes should be in extending planning practices towards database development and continuous urban research as well as making plan focus on infrastructure and density nexus. The second area of reforms is in educations of those engaged in city management, and advocacy towards mainstreaming PVC instruments in policy and legal instruments.

\section{Conflicts of Interest}

The author declares no conflicts of interest regarding the publication of this paper.

\section{References}

[1] Turok, I. (2016) Getting Urbanization to Work in Africa: The Role of the Urban Land-Infrastructure-Finance Nexus. Area Development and Policy, 1, 30-47. https://doi.org/10.1080/23792949.2016.1166444

[2] Goodfellow, T. (2017) Taxing Property in a Neo-Developmental State: The Politics of Urban Land Value Capture in Rwanda and Ethiopia. African Affairs, 116, 549-572. https://doi.org/10.1093/afraf/adx020

[3] Watson, V. (2014) African Urban Fantasies: Dreams or Nightmares? Environment and Urbanization, 26, 215-231. https://doi.org/10.1177/0956247813513705

[4] United Republic of Tanzania (2015) Migration and Urbanization Report-2012 Population and Housing Census Volume IV. Government Press, Dar es Salaam.

[5] Huang, C., Namangaya, A., Weber, M. and Cantada, I. (2018) Urban Planning Study for Tanzania-Impact and Effectiveness of Urban Planning on City Spatial Development World Bank Group.

[6] Berrisford, S., Cirolia, L.R. and Palmer, I. (2018) Land-Based Financing in Sub-Saharan 
African Cities. Environment and Urbanization, 30, 35-52. https://doi.org/10.1177/0956247817753525

[7] Famuyiwa, F. and KayodeBabawale, G. (2014) Hedonic Values of Physical Infrastructure in House Rentals. Journal of Facilities Management, 12, 211-230. https://doi.org/10.1108/JFM-05-2013-0027

[8] Worrall, L., Colenbrander, S., Palmer, I., Makene, F., Mushi, D., Mwijage, J. and Godfrey, N. (2017) Better Urban Growth in Tanzania: Preliminary Exploration of the Opportunities and Challenges.

[9] Collier, P. and Cust, J. (2015) Investing in Africa's Infrastructure: Financing and Policy Options. Annual Review of Resource Economics, 7, 473-493.

https://doi.org/10.1146/annurev-resource-100814-124926

[10] Foster, V. and Briceno-Garmendia, C. (2010) Africa's Infrastructure: A Time for Transformation: Africa Development Forum. World Bank, Washington DC. https://doi.org/10.1596/978-0-8213-8041-3

[11] Namangaya, A. and Kombe, W. (2016) Decentralisation and Urban Governance: Trends and Lessons from Cities in Tanzania. In: Decentralisation and Regional Development, Springer, Cham, 71-88. https://doi.org/10.1007/978-3-319-29367-7_5

[12] Calitz, E. and Fourie, J. (2010) Infrastructure in South Africa: Who Is to Finance and Who Is to Pay? Development Southern Africa, 27, 177-191. https://doi.org/10.1080/03768351003740449

[13] Smolka, M. (2013) Implementing Value Capture in Latin America: Policies and Tools for Urban Development. Lincoln Institute of Land Policy, Cambridge.

[14] Smolka, M. and Amborski, D. (2000) Value Capture for Urban Development: An Inter-American Comparison. Working Paper, Lincoln Institute of Land Policy, Cambridge.

[15] Petretta, D. (2015) How Can Value Capture Strategies Unlock Desperately Needed Funds? Getting Serious about Sustainable Transport Finance.

[16] Mathur, S. (2016) Innovation in Public Transport Finance: Property Value Capture. Routledge, Abingdon-on-Thames. https://doi.org/10.4324/9781315588636

[17] Alexander, E. (2012) Institutional Design for Value Capture and a Case: The Tel-Aviv Metropolitan Park. International Planning Studies, 17, 163-177. https://doi.org/10.1080/13563475.2012.673738

[18] Gielen, D., Salas, I. and Cuadrado, J. (2017) International Comparison of the Changing Dynamics of Governance Approaches to Land Development and Their Results for Public Value Capture. Cities, 71, 123-134. https://doi.org/10.1016/j.cities.2017.05.012

[19] Spaans, M., Janssen-Jansen, L. and van der Veen, M. (2011) Market-Oriented Compensation Instruments: Lessons for Dutch Urban Redevelopment. Town Planning Review, 82, 425-440. https://doi.org/10.3828/tpr.2011.25

[20] Van der Krabben, E. and Jacobs, H. (2013) Public Land Development as a Strategic Tool for Redevelopment: Reflections on the Dutch Experience. Land Use Policy, 30, 774-783. https://doi.org/10.1016/j.landusepol.2012.06.002

[21] Zhao, Z., Das, K. and Larson, K. (2012) Joint Development as a Value Capture Strategy for Public Transit Finance. Journal of Transport and Land Use, 5, 5-17. https://doi.org/10.5198/jtlu.v5i1.142

[22] Borrero, O. (2011) Betterment Levy in Colombia: Relevance, Procedures, and Social Acceptability. Land Lines, 23, 14-19.

[23] Immergluck, D. (2009) Large Redevelopment Initiatives, Housing Values and Gen- 
trification: The Case of the Atlanta Beltline. Urban Studies, 46, 1723-1745. https://doi.org/10.1177/0042098009105500

[24] Walter, L. (2016) Leveraging Land: Land-Based Finance for Local Governments: A Reader. UN-Habitat, Nairobi.

[25] Walters, L. (2013) Land Value Capture in Policy and Practice. Journal of Property Tax Assessment and Administration, 10, 5-22.

[26] Calabrò, F. and Spina, L. (2014) The Public-Private Partnerships in Buildings Regeneration: A Model Appraisal of the Benefits and for Land Value Capture. Advanced Materials Research, 931, 555-559. https://doi.org/10.4028/www.scientific.net/AMR.931-932.555

[27] Bahl, R. and Cyan, M. (2011) Tax Assignment: Does the Practice Match the Theory? Environment and Planning: Government and Policy, 29, 264-280. https://doi.org/10.1068/c1045r

[28] Mittal, J. (2014) Self-Financing Land and Urban Development via Land Readjustment and Value Capture. Habitat International, 44, 314-323. https://doi.org/10.1016/j.habitatint.2014.07.006

[29] der Krabben, E.V. and Needham, B. (2008) Land Readjustment for Value Capturing: A New Planning Tool for Urban Redevelopment. Town Planning Review, 79, 651-672. https://doi.org/10.3828/tpr.79.6.4

[30] Tan, R. and Heerink, N. (2017) Public and Self-Organized Land Readjustment in Rural China-A Comparison. Journal of Rural Studies, 53, 45-57. https://doi.org/10.1016/j.jrurstud.2017.04.006

[31] Mathur, S. (2008) Impact of Transportation and Other Jurisdictional-Level Infrastructure and Services on Housing Prices. Journal of Urban Planning and Development, 134, 32-41. https://doi.org/10.1061/(ASCE)0733-9488(2008)134:1(32)

[32] Vadali, S. (2008) Toll Roads and Economic Development: Exploring Effects on Property Values. Annals of Regional Science, 42, 591-620. https://doi.org/10.1007/s00168-007-0180-0

[33] Agostini, C. and Palmucci, G. (2008) The Anticipated Aapitalisation Affect of a New Metro Line on Housing Prices. Fiscal Studies, 29, 233-256. https://doi.org/10.1111/j.1475-5890.2008.00074.x

[34] Armstrong, R. and Rodriguez, D. (2006) An Evaluation of the Accessibility Benefits of Commuter Rail in Eastern Massachusetts Using Spatial Hedonic Price Functions. Transportation, 33, 21-43. https://doi.org/10.1007/s11116-005-0949-X

[35] Karanikolas, N. and Louka, E. (2012) The Effect of Metro Station on Commercial Values of Residential Properties. The Case Study of Thessaloniki, Greece before the Completion of the Metro Project Construction. International Journal of Academic Research, 4, 136-143.

[36] Peterson, G. (2008) Unlocking Land Values to Finance Urban Infrastructure. The World Bank, Washington DC. https://doi.org/10.1596/978-0-8213-7709-3

[37] Rodriguez, D. and Mojica, C. (2009) Capitalization of BRT Network Expansions Effects into Prices of Non-Expansion Areas. Transportation Research Part A, 43, 560-571. https://doi.org/10.1016/j.tra.2009.02.003

[38] Milan, B. (2015) The Good, the Bad and the Better of Value Capture. European Conference on Sustainable Urban Mobility Plans, Bucharest, 17 June 2015, 1-17.

[39] Kasala, S. and Burra, M. (2016) The Role of Public-Private Partnerships in Planned and Serviced Land Delivery in Tanzania. iBusiness, 8, 10-17.

https://doi.org/10.4236/ib.2016.81002 
[40] Namangaya, A. (2012) Evaluating the Essence of Zoning in Co-Managed Marine Protected Areas: The Case of Mnazi Bay Ruvuma Estuary Marine Park in Tanzania; in Reconciling Rural Livelihood and Biodiversity Conservation-SPRING Research Series.

[41] Nnkya, T. (1999) Land Use Planning Practice under the Public Land Ownership Policy in Tanzania. Habitat International, 23, 135-155. https://doi.org/10.1016/S0197-3975(98)00038-1

[42] Kironde, J. (2015) Good Governance, Efficiency and the Provision of Planned Land for Orderly Development in African Cities: The Case of the 20,000 Planned Land Plots Project in Dar es Salaam, Tanzania. Current Urban Studies, 3, 348. https://doi.org/10.4236/cus.2015.34028

[43] Namangaya, A. (2018) Practices in Institutionalizing GIS for Revenue Mobilisation: The Case of Secondary Cities in Tanzania. Current Urban Studies, 6, 559-572. https://doi.org/10.4236/cus.2018.64030

[44] McCluskey, W. and Franzsen, R. (2005) An Evaluation of the Property Tax in Tanzania: An Untapped Fiscal Resource or Administrative Headache? Property Management, 23, 43-69. https://doi.org/10.1108/02637470510580589

[45] Alananga, S., Lucian, C. and Kusiluka, M.M. (2015) Significant Cost-Push Factors in Owner-Built Incremental Housing Construction in Tanzania. Construction Management and Economics, 33, 671-688. https://doi.org/10.1080/01446193.2015.1090007

[46] Kombe, W. (2005) Land Use Dynamics in Peri-Urban Areas and Their Implications on Urban Growth and Form: The Case of Dar es Salaam, Tanzania. Habitat International, 29, 113-135. https://doi.org/10.1016/S0197-3975(03)00076-6

[47] Namangaya, A. and Kiunsi, R. (2018) Assessing the Influences of Service Provision on Pace and Short and Medium-Term Development Patterns of Residential Housing in Dar es Salaam. Geografisk Tidsskrift-Danish Journal of Geography, 118, 151-159. https://doi.org/10.1080/00167223.2018.1500490 